\title{
PENERAPAN MODEL PEMBELAJARAN INKUIRI TERBIMBING UNTUK MENINGKATKAN AKTIVITAS HASIL BELAJAR FISIKA DI KELAS XMIA 4 NEGERI 1 MUARO JAMBI
}

\author{
Yulianti ${ }^{1}$, Menza Hendri ${ }^{2}$, Rahma Dani ${ }^{3}$ \\ 1,2,3 Program Studi Pendidikan Fisika FKIP Universitas Jambi, Jambi, Indonesia \\ Email : yuliafary@yahoo.com
}

\section{Info Artikel}

\author{
Alamat Korespondensi: \\ Email :yuliafary@yahoo.com
}

\begin{abstract}
Abstrak:
Penelitian ini bertujuan untuk meningkatkan aktivitas dan hasil belajar fisika siswa dengan menggunakan model pembelajaraninkuiri terbimbing pada materi usaha dan energi. Penelitian ini merupakan penelitian tindakan kelas yang dilaksanakan dalam tiga siklus. Setiap siklus melalui tahap perencanaan, pelaksanaan,observasidan evaluasi, analisis dan refleksi. Subjek dalam penelitian ini adalah siswa kelas XMIA 4 SMA Negeri 1 Muaro Jambi tahun ajaran 2016/2017 yang berjumlah 30siswa yang terdiri dari 9 siswa laki-laki dan 21 siswa perempuan. Instrumen pengumpulan data dalam penelitian ini terdiri dari tes hasil belajar berupa tes objektif dan lembar observasi aktivitas siswa dan lembar observasi kegiatan guru. Teknik analisis data aktivitas siswasecara deskriptif kualitatif, data hasil observasi kegiatan guru dan tes hasil belajar dianalisis secara statistik deskriptif (mean, median, modus, standar deviasi maksimum dan minimum). Pada siklus I rata-rata persentase keaktifan siswa hanya 68,18 dan hasil belajar siswa 73,14. Kendala yang ditemukan seperti kurangnya keaktifan bertanya, mengemukakan pendapat mempresentasikan jawaban, menambahkan hasil jawaban, merangkum materi pelajaran. Solusinya adalah guru harus selalu memberi semangat dan motivasi kepada siswa agar terbiasa bertanya, memberikan pendapat, mempresentasikan jawaban, menambahkan hasil jawaban, dan merangkum materi pelajaran. Pada siklus II rata-rata persentase keaktifan siswa menjadi 73,14dan hasil belajar siswa 74,73. Kendala yang ditemukan yaitu siswa cukup aktif bertanya, mengemukakan pendapat, mempresentasikan jawaban, menambahkan hasil jawaban. Solusinya adalahguru harus selalu memberi semangat dan motivasi kepada siswa agar terbiasa bertanya, memberikan pendapat, mempresentasikan jawaban, menambahkan hasil jawaban. Pada siklus III rata-rata persentase keaktifan siswa menjadi 74,73dan hasil belajar mencapai KKM yaitu ratarata 76,36. Hal ini menunjukkan bahwa terjadi peningkatan aktivitas dan hasil belajar siswa dalam pembelajaran. Dengan demikian, dapat disimpulkan bahwa penerapanmetode pembelajaran Inkuiri Terbimbing Untuk Meningkatkan Aktivitas Hasil Belajar Fisika Di Kelas X MIA 4 Negeri 1 Muaro Jambi.
\end{abstract}

Kata kunci:Aktivitas, Hasil Belajar, Inkuiri Terbimbing. 


\section{Pendahuluan}

Slameto (2013), mengatakan bahwa dalam proses belajar mengajar, guru perlu menimbulkan aktivitas siswa dalam berpikir maupun berbuat. Penerimaan pelajaran jika dengan aktivitas siswa sendiri, kesan itu tidak akan berlalu begitu saja, tetapi dipikirkan, diolah kemudian dikeluarkan lagi dalam bentuk yang berbedaatau siswa akan bertanya, mengajukan pendapat, menimbulkan diskusi dengan guru. Bila siswa menjadi aktif, maka ia memiliki ilmu/pengetahuan itu dengan baik.

Berdasarkan hasil observasi yang dilakukan di SMA Negeri 1 Muaro Jambi pada tanggal 02maret 2017 di kelas XMIA 4, dapat diketahui bahwa pada saat proses belajar mengajar berlangsung aktivitas belajar siswa di dalam kelas sangat kurang aktif, dari 30 siswa dikelas hanya sedikit sekali siswa yang mau merespon dan bertanya ketika guru memberikan kesempatan kepada siswa untuk bertanya tentang materi pelajaran. Model yang diterapkan di SMA Negeri 1 Muaro Jambi selama ini masih banyak menggunakan model konvensional melalui ceramah dan tanya jawab sehingga kesan proses pembelajarantersebut hanya terpusat pada guru bukan siswa dan kondisi didalam kelas menjadi pasif.

Hal ini dapat dilihat pada nilai ratarata ulangan harian siswa kelas X MIA 4 di SMANegeri 1 Muaro jambi di bawah tingkat ketuntasan belajar.Khusus untuk mata pelajaran fisika, kriteria ketuntasan minimal (KKM) di SMA Negeri 1 Muaro Jambi adalah 75. Berikut data rata-rata hasil ulangan fisika Kelas X MIA 4 SMA Negeri 1 Muaro Jambi :

Tabel 1 Nilai Ulangan Siswa Kelas X MIA 4 SMA Negeri 1 Muaro Jambi TA 2016/2017

\begin{tabular}{cc}
\hline Kelas & Rata - rata \\
\hline X MIA 1 & 72 \\
X MIA 2 & 70 \\
X MIA 3 & 65 \\
X MIA 4 & 60 \\
\hline
\end{tabular}

Hasil wawancara yang dilaksanakan pada tanggal 13 Agustus 2016 dengan guru mata pelajaran fisika kelas XI IPA 4, beliau mengungkapkan ada beberapa faktor penyebab rendahnya hasil belajar fisika diantaranya adalah siswa kurang aktif dalam mengajukan pertanyaan, menjawab dan memberikan pendapat ketika ditanyakan oleh guru, siswa kurang fokus selama proses pembelajaran dan juga sarana dan prasarana di SMA N 8 Muaro Jambi kurang memadai, maka dari itu pembelajaran lebih banyak menggunakan metode ceramah.

Dari hasil wawancara dengan beberapa siswa kelas XI IPA 4, diketahui rendahnya hasil belajar fisika siswa dikarenakan mereka beranggapan fisika adalah pelajaran yang sulit karena terlalu banyak rumusnya, kurang bersemangat untuk belajar, model dan metode yang digunakan guru kurang bervariasi sehingga banyak siswa yang bosan pada saat pembelajaran berlangsung. Aktivitas belajar siswa rendah dikarenakan siswa kurang aktif bertanya pada saat guru memberi kesempatan dikarenakan mereka tidak mengerti dan kurang paham terhadap materi yang diberikan dan juga mereka tidak tahu pertanyaan apa yang harus ditanyakan kepada guru.

Berdasarkan gejala-gejala di atas, dapat dikatakan bahwa aktivitas belajar siswa dalam proses pembelajaran fisika cenderung rendah. Untuk itu, melalui penelitian ini penulis berusaha untuk memperbaiki aktifitas belajar siswa dalam proses pembelajaran. Menurut Suparno (2027),Inkuiri Terbimbingadalah inkuiri yang banyak di campuri oleh guru. Tujuan Inkuiri adalah mengembangkan kemampuan intelektual sebagai bagian proses mental, selain juga ditujukan untuk meningkatkan pengetahuan, kemampuan, serta keaktifan siswa dengan belajar kelompok. Hariyanto (2015) menyatakan bahwa model pembelajaran Inkuiri Terbimbingdapat meningkatkan aktivitas dan hasil belajar fisika siswa. Adapun langkah-langkah pelaksanaan pembelajaran Inkuiri Terbimbing Menurut Suparno (2007) sebagai berikut:

1. Identifikasi dan klarifikasi persoalan, yaitu Menemukan Persoalan yang ingin dialami atau dipecahkan dengan model inkuiri.

2. Membuat hipotesis yaitu Memintak siswa untuk mengajukan jawaban sementara tentang persoalan itu.

3. Mengumpul Data yaitu Mencari dan menggumpul data sebanyakbanyaknya untuk membuktikan 
apakah hipotesis mereka benar atau tidak.

4. Menganalisis Data,yaitu Data yang sudah dikumpulkan harus dianalisis untuk membuktikan hipotesis apakah benar atau salah. Untuk memudahkan menganalisis data, data sebaiknya dikelompokkan,diatur sehingga dapat di baca.

5. Mengambil Data, yaitu Data yang telah di kelompokan dan dianalisis, kemudian diambil kesimpulan dengan generalisasi. Setelah di ambil kesimpulan, kemudian dicocokkan dengan hipotesis awal, apakah hipotesis diterima atau tidak.

Adapun Langkah-langkah model pembelajran inkuiri menurut putra (2013), sebagai berikut:

1. Orientasi. Guru melakukan langkah untuk membina suasana atau iklim yang kondusif.

2. Merumuskan masalah merupakan langkah membawa siswa kepada suatu persolan yang mengundang teka-teki. Persoalan yang disajikan adalah persoalan yang menantang siswa untuk memecahkan persoalan. Proses mencari jawaban itulah yang sangat penting dalam pembelajaran inkuiri.

3. Merumuskan hipotesisJawaban sementaradari suatu permasalahan yang disajikan. Salah satu cara yang dapat dilakukan oleh guru untuk mengembangkan kemampuan berhipotesis ialah mengajukan pertanyaan yang bisa mendorong siswa supaya dapat merumuskan jawaban sementara atau perkiraan.

4. Mengumpulkan data. Mengumpulkan data adalah aktivitas menjaring informasi yang dibutuhkan untuk menguji hipotesis yang diajukan. Mengumpulkan data merupakan proses mental yang sangat penting dalam pengembangan intelektual.

5. Menguji hipotesis. Menguji hipotesis adalah menentukan jawaban yang dianggap diterima sesuai dengan data atau informasi yang diperoleh berdasarkan pengumpulan data. Menguji hipotesis berarti mengembangkan kemampuan berfikir rasional.

6. Merumuskan

kesimpulanMerumuskan kesimpulan adalah proses mendeskripsikan temuan yang diperoleh berdasarkan hasil pengujian hipotesis. Untuk mencapai kesimpulan yang akurat guru mampu menunjukan kepada siswa tentang data-data yang relevan.

Kelebihan model pembelajaran Inkuiri Terbimbing menurut Ibrahim (2010) adalah a) Siswa mengembangkan kemampuan berpikir melalui observasi spesifik hingga membuat inferensi atau genenrasai. b) Sasarannya adalah mempelajari proses mengamati kejadian atau objek kemudian menyusun generasi yang sesuai. c) Guru mengontrol bagian tertentu dari pembelajaran misalnya kejadian,data,materi dan berperan sebagai pemimpin kelas. d) Tiap-tiap siswa berusaha untuk membangun pola yang bermakna berdasarkan hasil observasi di dalam kelas. e) Kelas di harapkan berfungsi sebangai laboratorium pembelajaran. f) Biasanya sejumlah generalisasi tertentu akan diperoleh dari siswa. g) Guru memotivasi semua siswa untuk mengkomunikasikan hasil generalisasinya sehingga dapat dimanfaatkan oleh seluruh siswa dalam kelas.

Berdasarkan uraian di atas tujuan penelitian ini adalah untuk meningkatkan aktivitas dan hasil belajar siswa kelas X MIA 4 SMA Negeri Muaro Jambi dengan menggunakan model pembelajaran Inkuiri Terbimbing dalam pokok bahasan usaha dan energi. Adapun kegunaan penelitian ini adalah a) Bagi peneliti, dapat memperoleh pengalaman langsung dalam meningkatkan aktivitas dan hasil belajar dan menerapkan model yang tepat dalam pembelajaran serta menambah pengetahuan dan bekal pengalaman sebagai calon guru. b) Bagi siswa, diharapkan melalui penerapan model pembelajaran Inkuiri Terbimbingdapat menigkatkan aktivitas dan hasil belajar fisika. c) Bagi guru dan sekolah, dapat memberi masukan dan gambaran bagaimana semestinya proses pembelajaran berlangsung sehingga menerapkan berbagai model pembelajaran dalam proses belajar mengajar. 


\section{Metode Penelitian}

Jenis penelitian

Jenis penelitian ini adalah penelitian tindakan kelas (classroom action research).Penelitian tindakan kelas (PTK) merupakan perpaduan antara tindakan (action) dan penelitian (research) yang dilakukan oleh guru di dalam kelas.

Tempat penelitian

Penelitian tindakan kelas ini dilaksanakan di kelas XI IPA 4 Semester 1 SMA Negeri 8 Muaro Jambi tahun ajaran 2016/2017.

Subyek penelitian

Subyek dalam penelitian ini adalah siswa kelas XMIA 4 SMA Ngeri 1 Muaro Jambi tahun ajaran 2016/2017 berjumlah 30 siswa dengan 9 siswa laki - laki dan 21 siswa perempuan.

\section{Rancangan Penelitian}

Penelitian ini dilaksanakan dalam tiga siklus yaitu terdiri dari siklus I, siklus II , dan siklus III. Dalam penelitian ini peneliti bekerja sama dengan guru bidang studi fisika yang mengajar di kelas tersebut. Dalam hal ini peneliti sebagai pengajar dan guru bidang studi fisika sebagai pengamat dalam setiapa kegiatan belajar yang berlangsung. Pada setiap siklus memilki tahapan-tahapan tertentu sesuai dengan tahapan dalam tindakan kelas yang dikemukakan oleh Arikunto (2013), yaitu (1) perencanaan, (2) pelaksanaan, (3) pengamatan, dan (4) refleksi.

Instrumen Penelitian

Lembar Observasi

Pada penelitian ini dilakukan observasi proses pembelajaran menggunakan model pembelajaran Inkuiri Terbimbingterhadap guru dan aktivitas siswa. Lembar observasi dibuat berdasarkan sintak pembelajaran yang ada di RPP. Sebelum melakukan observasi maka pengamat harus memahami betul kriteria dalam menganalisa gejala yang terlihat pada objek sehingga tidak keliru dalam mengambil keputusan. Selain itu agar hasil oberservasi dapat lebih objektif maka observasi dilakukan pada setiap proses pembelajaran yang dilakukan oleh rekan guru pengamat.

\section{Tes Hasil Belajar}

Dalam penelitian ini digunakan instrumen tes berupa tes objektif dengan alternatif pilihan yang memenuhi syarat standar soal yaitu validitas, tingkat kesukaran tiap soal, daya pembeda dan reliabilitas yang memenuhi kriteria tertentu. Agar soal tes yang digunakan berkualitas, soal dilakukan analisis sebagai berikut:

\section{Validitas Tes}

Validitas tes adalah tingkat ketepatan tes. Sehubung dengan penelitian ini maka validitas yang digunakan adalah validitas isi. Menurut Arikunto (2013) sebuah tes dikatakan memiliki validitas isi apabila mengukur tujuan khusus tertentu yang sejajar dengan materi atau isi pelajaran yang diberikan.Tujuan digunakan validitas isi yaitu untuk menguji ketepatan isi dan keabsahan soal sebagai instrumen penelitian sehingga data yang diperoleh dari hasil tes tersebut dapat dipercaya kebenarannya. Oleh sebab itu penulis membuat kisi-kisi soal dan soal tes yang sesuai dengan materi yang diajarkan tertera dalam kurikulum.

\section{Tingkat Kesukaran}

Untuk menghitung seberapa besar tingkat kesukaran soal dapat dihitung dengan menggunakan rumus yang dikemukakan oleh Arikunto (2013), sebagai berikut:

Di mana:

$$
P=\frac{B}{J S}
$$

$\mathrm{P} \quad=$ Indeks kesukaran

$\mathrm{B}$ = Banyaknya siswa yang menjawab soal itu dengan betul

JS = Jumlah seluruh siswa peserta tes Klarifikasi indeks kesukaran butir soal

(Arikunto, 2013) adalah sebagai berikut:

- Soal dengan P 0,00 sampai 0,30 adalah soal sukar

- Soal dengan P 0,30 sampai 0,70 adalah soal sedang

- Soal dengan P 0,70 sampai 1,00 adalah soal mudah 
Tabel 2 Nilai Indeks Kesukaran

\begin{tabular}{cc}
\hline $\mathrm{P}($ Tingkat Kesukaran $)$ & Kategori \\
\hline $0,00-0,32$ & Sukar \\
$0,33-0.66$ & Sedang \\
$0.67-1.00$ & mudah \\
\hline
\end{tabular}

Sumber Purwanto : (2014)

Daya Beda

Daya pembeda soal adalah kemampuan suatu soal untuk membedakan antara siswa yang pandai (berkemampuan tinggi) dengan siswa yang bodoh (berkemampuan rendah). Rumus untuk menentukan indeks diskriminasi menurut Arikunto (2013) adalah sebagai berikut:

Di mana:

$$
D=\frac{B_{A}}{J_{A}}-\frac{B_{B}}{J_{B}}
$$

Dengan :

$\mathrm{DB}=$ Daya pembeda

$\mathrm{BA}=$ Banyaknya peserta atas yang menjawab benar

$\mathrm{BB}=$ Banyaknya peserta bawah yang menjawab benar

$\mathrm{JA}=$ Banyaknya peserta kelompok atas

$\mathrm{JB}=$ Banyaknya peserta kelompok bawah

Klasifikasi daya pembeda menurut Arikunto (2013) adalah sebagai berikut:

D : $0,00-0,20$ : jelek (poor)

D : $0,20-0,40$ : cukup (satisfactory)

D : $0,40-0,70$ : baik (good)

D : $0,70-1,00$ : baik sekali (excellent)

D : negatif, semuanya tidak baik, jadi semua

butir soal yang mempunyai nilai $\mathrm{D}$ negatif sebaiknya dibuang saja.

Reliabilitas

Untuk menentukan reliabilitas dalam penelitian ini digunakan rumus KuderRichardson (K-R21) yang dikemukakan oleh Arikunto (2013) yaitu:

Dengan :

$$
r_{11}=\left(\frac{k}{k-1}\right)\left(1-\frac{M(M-n)}{n S t^{2}}\right)
$$

$$
\begin{gathered}
S_{t}^{2}=\frac{\sum X^{2}-\frac{\left(\sum X\right)^{2}}{N}}{N} \\
M=\frac{\sum X}{N}
\end{gathered}
$$

Keterangan :

$\mathrm{r}_{11}=$ Reliabilitas instrumen

$\mathrm{n} \quad=$ Banyaknya butir soal
$\mathrm{N}=$ Jumlah peserta tes

$\mathrm{M}=$ Mean

$\mathrm{S}_{\mathrm{t}}^{2}=$ Variansi

$\sum \mathrm{x}=$ Jumlah skor yang dijawab oleh seluruh siswa

$\sum \mathrm{x}^{2}=$ Jumlah skor total yang dikuadratkan Koefisien reliabilitas tes berkisar antara 0,00 sampai dengan 1,00 dengan perincian korelasi seperti pada tabel berikut:

Tabel 3 Koefisien Reliabilitas

\begin{tabular}{cc}
\hline Nilai $\mathbf{r}$ & Keterangan \\
\hline $0,81<\mathrm{r} \leq 1,00$ & Sangat Tinggi \\
$0,61<\mathrm{r} \leq 0,80$ & Tinggi \\
$0,41<\mathrm{r} \leq 0,60$ & Sedang \\
$0,21<\mathrm{r} \leq 0,40$ & Rendah \\
$0,00<\mathrm{r} \leq 0,20$ & Sangat Rendah \\
\hline \multicolumn{2}{c}{ (Sumber Arikunto $: 2013)$}
\end{tabular}

\section{Analisis Data}

Data kualitatif diambil dari data hasil observasi tentang situasi belajar mengajar, yaitu untuk data hasil observasi aktivitas siswa dihitung dengan menggunakan persamaan :

Keterangan :

$$
A=\frac{N a}{N} \times 100 \%
$$

$A=$ Aktivitas siswa

$\mathrm{Na}$ = Jumlah siswa yang aktif

$N=$ Jumlah siswa keseluruhan

Dengan perhitungan penilaiannya sebagai berikut:

$$
\begin{aligned}
& 0-20=\text { Tidak Aktif } \\
& 21-40=\text { Kurang aktif } \\
& 41-60=\text { Cukup aktif } \\
& 61-80=\text { Aktif } \\
& 81-100=\text { Sangat aktif }
\end{aligned}
$$

Data kuantitatif hasil belajar siswa diperoleh dari hasil tes soal yang diberikan. Pada tahap evaluasi dilakukan perhitungan yang dikemukakan oleh Arikunto (2013), dengan menggunakan persamaan berikut :

$$
\begin{aligned}
& \mathrm{S}=\text { Skor } \\
& \mathrm{R}=\text { Jumlah Jawaban benar } \\
& \mathrm{Wt}=\text { Bobot } \\
& \mathrm{W}=\text { Jumlah jawaban salah }
\end{aligned}
$$


$\mathrm{n}$ = Jumlah option (banyaknya pilihan jawaban)

Mean

Nilai rata-rata kelas dihitung dengan persamaan yang dikemukakan oleh sudjana (2013),sebagai berikut:

Keterangan :

$$
\bar{x} \text { ? }=\frac{\sum N a}{N}
$$

$\bar{x}=$ Nilai rata-rata

$\mathrm{Na}=$ Jumlah nilai ulangan siswa

$N=$ Jumlah siswa keseluruhan

Median

Untuk menentukan nilai tengah dari data yang telah diurutkan (disusun) dari data terkecil

sampai data terbesar, dengan menggunakan rumus yang dikemukakan oleh Riduwan (2010), sebagai berikut:

Keterangan :

$$
M e=\frac{1}{2}(n+1)
$$

$\mathrm{Me}=$ Median

$\mathrm{n}=$ Jumlah data

Modus

Untuk mencari nilai dari beberapa data yang mempunyai frekuensi tertinggi baik data tunggal maupun data yang berbentuk distribusi atau nilai yang sering muncul dalam kelompok data.

Standar Deviasi

Untuk menentukan suatu nilai yang menunjukan tingkat (derajat) variasi

kelompok data atau ukuran standar penyimpangan dari meannya dapat dihitung menggunakan rumus yang dikemukakan oleh Riduwan (2010), sebagai berikut :

$$
S=\frac{\sum X^{2}-\frac{\left(\sum X\right)^{2}}{n}}{n-1}
$$

Keterangan :

$\mathrm{S}=$ Standar Deviasi

$\mathrm{n} \quad=$ Banyaknya butir soal

$\sum \mathrm{x}=$ Jumlah skor yang dijawab oleh seluruh siswa

$\sum \mathrm{x}^{2}=$ Jumlah skor total yang dikuadratkan

Untuk menghitung presentase tingkat keberhasilan belajar digunakan persamaan yang dikemukakan oleh Arikunto (2013), sebagai berikut:

$$
\text { Nilai }=\frac{\text { skor mentah }}{\text { skor maksimum }} \times 100
$$

\section{Hasil Dan Pembahasan}

\section{Siklus I}

Siklus I merupakan pelaksanaan tindakan awal yang dilakukan pada pelaksanaan penelitian tindakan kelas. Pada siklus I pelaksanaan tindakan dilakukan dua kali pertemuan dan satu kali ujian siklus. Pertemuan I membahas tentang sub pokok bahasan pengertian hubungan antara usaha gaya dan perpindahan, sedangkan pertemuan II membahas tentang sub pokok energi pontesial gravitasi. Langkah-langkah pembelajaran siklus I dilaksanakan sesuai dengan Rencana Pelaksanaan Pembelajaran (RPP) I dan Rencana Pelaksanaan Pembelajaran (RPP) II.

Proses pembelajaran pada siklus ini dilaksanakan sesuai dengan model pembelajaran Inkuiri Terbimbing. Dalam penelitian pada siklus I ini pelaksanaan pembelajaran yang dilakukan oleh penulis diamati oleh salah satu guru bidang studi fisika SMAN 1Muaro Jambi.

Hasil dari penelitian peneliti pada siklus I dapat dilihat pada tabel-tabel di bawah ini:

Tabel 6 Rata-rata aktivitas siswa pada proses pembelajaran siklus I

\begin{tabular}{ccc}
\hline Yang diamati & $\begin{array}{c}\text { Persentase } \\
(\%)\end{array}$ & Kategori \\
\hline Rata-rata & 68,65 & Aktif \\
aktivitas & & \\
pembelajaran \\
siswa & & \\
\hline
\end{tabular}

Tabel 7 Hasil belajar siswa pada siklus I

\begin{tabular}{lcl}
\hline \multicolumn{1}{c}{ Yang diamati } & Jumlah & $\%$ \\
\hline Siswa yang tes & 30 & 100 \\
Nilai rata-rata siswa & 72,18 & 72,18 \\
Siswa yang mencapai & 9 & 40,91 \\
KKM & & \\
Siswa yang belum & 13 & 59,09 \\
mencapai KKM & & \\
Median & 70 & 70 \\
Modus & 7 & 60 \\
Standar deviasi & 44,69 & 44,69 \\
Nilai maksimum & 5 & 90 \\
Nilai minimum & 7 & 60 \\
\hline
\end{tabular}


Hal ini disebabkan oleh beberapa kendala pada aktivitas siswa dan kegiatan guru pada proses pembelajaran. Adapun kendala pada aktivitas siswa dan guru yaitu: 1) kurangnya keaktifan siswa dalam bertanya mengenai materi yang belum dimengerti 2) kurangnya keaktifan siswa dalam mengemukakan pendapat mengenai penyelesaian soal yang belum dipahami kepada kelompok yang mempresentasikan 3) kurangnya keaktifan siswa dalam mempresentasikan jawaban dari pertanyaan yang sudah diperolehnya dan mendiskusikannya didepan kelas.Sedangkan kendala pada kegiatan guru yaitu: 4) guru harus lebih terampil membimbing siswa untuk mempresentasikan jawaban dari pertanyaan yang sudah diperolehnya dan lebih tegas meminta siswa untuk menambahkan hasil jawaban dari kelompok lain 5). guru harus lebih tegas untuk meminta siswa marangkum materi pelajaran.

Solusi dari kendala-kendala yang ditemukan pada aktivitas guru dan siswa siklus I yaitu: Solusinya adalah: 1) guru harus selalu memberi semangat dan motivasi kepada siswa agar terbiasa bertanya mengenai materi yang belum dimengerti 2) guru harus lebih tegas meminta siswa untuk memberikan pendapat terhadap kelompok yang sedang mempresentasikan jawabannya 3) guru harus lebih tegas dalam meminta siswa untuk mempresentasikan jawaban dari soal yang diperolehnya 4) guru harus lebih terampil membimbing siswa untuk mempresentasikan jawaban dari pertanyaan yang sudah diperolehnya dan lebih tegas meminta siswa untuk menambahkan hasil jawaban dari kelompok lain 5) guru harus lebih tegas untuk meminta siswa marangkum materi pelajaran.

\section{Siklus II}

Dengan adanya perbaikan pada proses pembelajaran siklus II, aktivitas diskusi kelompok dan hasil belajar siswa pada siklus II ini mengalami peningkatan. Hal ini ditunjukkan pada tabel-tabel di bawah ini:
Tabel 8 Rata-rata aktivitas siswa pada proses pembelajaran siklus II

\begin{tabular}{ccc}
\hline Yang diamati & $\begin{array}{c}\text { Persentase } \\
(\%)\end{array}$ & Kategori \\
\hline Rata-rata & 76,60 & Aktif \\
aktivitas & & \\
pembelajaran \\
siswa
\end{tabular}

Tabel 9 Hasil belajar siswa pada siklus II

\begin{tabular}{lcc}
\hline \multicolumn{1}{c}{ Yang diamati } & Jumlah & $\%$ \\
\hline Siswa yang tes & 30 & 100 \\
Nilai rata-rata siswa & 73,14 & 73,14 \\
Siswa yang mencapai & 12 & 54,55 \\
KKM & & \\
Siswa yang belum & 10 & 45,45 \\
mencapai KKM & & \\
Median & 75 & 75 \\
Modus & 7 & 66,7 \\
Standar deviasi & 45,60 & 45,60 \\
Nilai maksimum & 4 & 91,6 \\
Nilai minimum & 3 & 58,3 \\
& & \\
\hline
\end{tabular}

Meskipun aktivtas siswa dan hasil belajar meningkat dari siklus sebelumnya, namun rata-rata hasil belajar siswa masih berada di bawah KKM yang ditetapkan. Hal ini disebabkan oleh beberapa kendala pada aktivitas siswa dan guru pada proses pembelajaran. Adapun kendala pada aktivitas siswa dan guru yaitu: 1) siswa cukup aktif dalam bertanya mengenai materi yang belum dimengerti 2) siswa cukup aktif dalam mengemukakan pendapat mengenai penyelesaian soal yang belum dipahami kepada kelompok yang mempresentasikan 3) siswa cukup aktif dalam mempresentasikan jawaban dari pertanyaan yang sudah diperolehnya dan mendiskusikannya didepan kelas.

Sedangkan kendala pada kegiatan guru yaitu: 4) guru cukup aktif dalam meminta siswa lainnya untuk menambahkan hasil jawaban dari kelompok lain.

Solusi dari kendala-kendala yang ditemukan pada aktivitas guru dan siswa siklus II yaitu: 1) guru harus selalu memberi semangat dan motivasi kepada siswa agar terbiasa bertanya mengenai materi yang belum dimengerti 2) guru harus lebih tegas meminta siswa untuk memberikan pendapat terhadap kelompok yang sedang mempresentasikan jawabannya 3) guru harus 
lebih tegas dalam meminta siswa untuk mempresentasikan jawaban dari soal yang diperolehnya 4) guru harus lebih terampil membimbing siswa untuk mempresentasikan jawaban dari pertanyaan yang sudah diperolehnya dan lebih tegas meminta siswa untuk menambahkan hasil jawaban dari kelompok lain.

\section{Siklus III}

Perbaikan yang dilakukan pada proses pembelajaran meningkatkan aktivitas diskusi kelompok dan hasil belajar siswa. Hal ini ditunjukkan pada tabel-tabel di bawah ini:

Tabel 10 Rata-rata aktivitas siswa pada proses pembelajaran siklus III

\begin{tabular}{ccc}
\hline Yang diamati & $\begin{array}{c}\text { Persentase } \\
(\%)\end{array}$ & Kategori \\
\hline Rata-rata & 84,16 & Aktif \\
aktivitas & & \\
pembelajaran & & \\
siswa & & \\
\hline
\end{tabular}

Tabel 11 Hasil belajar siswa pada siklus III

\begin{tabular}{llc}
\hline \multicolumn{1}{c}{ Yang diamati } & Jumlah & \multicolumn{1}{c}{$\%$} \\
\hline Siswa yang tes & 30 & 100 \\
Nilai rata-rata siswa & 79,58 & 79,58 \\
Siswa yang mencapai & 19 & 79,17 \\
KKM & & \\
Siswa yang belum & 5 & 20,83 \\
mencapai KKM & & \\
Median & 80 & 80 \\
Modus & 13 & 80 \\
Standar deviasi & 48,23 & 48,23 \\
Nilai maksimum & 6 & 90 \\
Niali minimum & 2 & 60 \\
\hline
\end{tabular}

Pada siklus III aktivitas siswa telah mencapai kategori aktif. Untuk rata-rata hasil belajar siswa sudah mencapai kriteria ketuntasan minimum,Hal ini terlihat dari 30 orang yang mengikuti tes evaluasi siklus III, jumlah siswa yang berhasil 24 orang atau $79,17 \%$ dari jumlah siswa yang mengikuti tes yang nilainya berada di atas Kriteria Ketuntasan Minimum (KKM). Nilai rata-rata siswa sudah memenuhi apa yang diharapkan yaitu 79,58, hal ini menunjukkan bahwa pelaksanaan proses pembelajaran pada siklus III ini telah berhasil dan telah mencapai target yang telah diinginkan meskipun ada siswa yang masih berada dibawah kriteria ketuntasan minimum.

\section{Simpulan dan Saran}

Simpulan

Berdasarkan hasil penelitian tindakan kelas yang telah dilaksanakan, dapat disimpulkan bahwa pelaksanaan pembelajaran dengan menerapkan model pembelajaran Inkuiri Terbimbing dapat meningkatkan aktivitas dan hasil belajar fisika siswa pada materi Suhu dan Kalor di SMA Negeri 1 Muaro Jambi. Pada siklus I hasil belajar diperoleh siswa pada aspek pengetahuan dalam pelaksanaan tindakan siklus I ini masih rendah, dari 30 orang siswa yang mengikuti tes hasil belajar 16 siswa yang berhasil atau $41,66 \%$ dari jumlah siswa keseluruhan yang nilainya berada di atas KKM yaitu $\geq 75$. Sedangkan siswa yang belum mencapai KKM yakni 14 siswa 58,33\%. Nilai rata-rata siswa masih rendah yaitu 73,75 . Dan rata-rata persentase aktivitas siswa adalah $68,65 \%$. Hal ini menujukan bahwa pelaksanaan proses pembelajaran pada siklus I ini masih terdapat kekurangan dan perlu ditingkatkan pada siklus selanjutnya. Adapun kendala pada siklus I yaitu: 1) kurangnya keaktifan siswa dalam bertanya mengenai materi yang belum dimengerti 2) kurangnya keaktifan siswa dalam mengemukakan pendapat mengenai penyelesaian soal yang belum dipahami kepada kelompok yang mempresentasikan 3) kurangnya keaktifan siswa dalam mempresentasikan jawaban dari pertanyaan yang sudah diperolehnya dan mendiskusikannya didepan kelas 4) kurangnya keaktifan guru dalam meminta siswa lainnya untuk menambahkan hasil jawaban dari kelompok lain 5) kurangnya keaktifan guru dalam meminta siswa merangkum materi pelajaran. Solusinya adalah: 1) guru harus selalu memberi semangat dan motivasi kepada siswa agar terbiasa bertanya mengenai materi yang belum dimengerti 2) guru harus lebih tegas meminta siswa untuk memberikan pendapat terhadap kelompok yang sedang mempresentasikan jawabannya 3) guru harus lebih tegas dalam meminta siswa untuk mempresentasikan jawaban dari soal yang diperolehnya 4) guru harus lebih terampil membimbing siswa untuk mempresentasikan jawaban dari pertanyaan yang sudah diperolehnya dan lebih tegas meminta siswa untuk menambahkan hasil jawaban dari 
kelompok lain 5) guru harus lebih tegas untuk meminta siswa marangkum materi pelajaran.

Pada siklus II rata-rata persentase aktivitas siswa adalah $73,14 \%$ dan rata-rata hasil belajar siswa masih rendah yaitu $74,73 \%$ dengan 12 siswa atau $54,55 \%$ yang berhasil mencapai KKM dan 10 siswa atau 45,45\% yang belum mencapai KKM. Hal ini menunjukan bahwa peningkatan hasil belajar pada siklus II perlu ditingkatkan pada siklus selanjutnya. Adapun kendala yang dihadapi pada pelaksanaan proses belajar mengajar pada siklus II yaitu: 1) siswa cukup aktif dalam bertanya mengenai materi yang belum dimengerti 2) siswa cukup aktif dalam mengemukakan pendapat mengenai penyelesaian soal yang belum dipahami kepada kelompok yang mempresentasikan 3) siswa cukup aktif dalam mempresentasikan jawaban dari pertanyaan yang sudah diperolehnya dan mendiskusikannya didepan kelas 4) guru cukup aktif dalam meminta siswa lainnya untuk menambahkan hasil jawaban dari kelompok lain

Solusinya adalah: 1) guru harus selalu memberi semangat dan motivasi kepada siswa agar terbiasa bertanya mengenai materi yang belum dimengerti 2) guru harus lebih tegas meminta siswa untuk memberikan pendapat terhadap kelompok yang sedang mempresentasikan jawabannya 3) guru harus lebih tegas dalam meminta siswa untuk mempresentasikan jawaban dari soal yang diperolehnya 4) guru harus lebih terampil membimbing siswa untuk mempresentasikan jawaban dari pertanyaan yang sudah diperolehnya dan lebih tegas meminta siswa untuk menambahkan hasil jawaban dari kelompok lain.

Pada siklus III sudah mengalami peningkatan keaktifan siswa dalam proses pembelajaran juga diiringi dengan peningkatan hasil belajar yang didapat siswa tiap akhir siklus. Nilai rata-rata persentase aktivitas siswa adalah $84,16 \%$ dan hasil belajar rata-rata siswa pada siklus III adalah $79,58 \%$ dengan jumlah siswa yang berhasil sebanyak 19 siswa atau 79,17\% dan siswa yang tidak berhasil sebanyak 5 siswa atau $20,83 \%$.

Hasil dan aktivitas belajar setiap
siklus bisa meningkat dikarenakan
kekurangan yang ada pada proses
pembelajaran dilakukan refleksi guna untuk

tercapainya nilai yang sesuai dengan indikator yang ditetapkan di sekolah.

Saran

Berdasarkan kesimpulan yang
diperoleh di atas serta untuk lebih
meningkatkan aktivitas dan hasil belajar
siswa, maka penulis menyarankan beberapa
hal: hal:

1. Sebelum pembelajaran fisika dengan model pembelajaran Inkuiri Terbimbing ini dimulai, hendaknya diperhatikan dalam mengalokasikan waktu untuk setiap kegiatan agar semua kegiatan dalam kegiatan belajar mengajar dapat terlaksana dengan baik, dikarenakan model pembelajaran ini memerlukan waktu yang cukup panjang.

2. Dalam proses pembelajaran guru perlu menekankan dan menciptakan persepsi bahwa keberhasilan setiap siswa (individu) ditentukan oleh kelompoknya, dan ketua kelompok harus bertanggung jawab sebagai peer tutoring (tutor sebaya) agar sintak dari Inkuiri Terbimbingdapat terlaksana dengan baik.

3. Pada saat pemberian kuis, ada baiknya skor tiap individu langsung dihitung dan dijumlahkan dengan masing-masing kelompoknya untuk mengetahui kelompok mana yang skornya tinggi dan kelompok yang skornya rendah, agar tiap kelompok semangat dalam proses pembelajaran berikutnya.

4. Karena penelitian ini hanya dilakukan pada materi Usaha dan Energi, maka diharapkan penelitian yang serupa dapat pula dilaksanakan pada materi fisika yang lainnya.

\section{Daftar Pustaka}

Arikunto, S. 2013. Prosedur Penelitian Suatu Pendekatan Praktik (Edisi Revisi 2013). Jakarta: PT. Rineka Cipta

Hamalik, O. 2013. Proses Belajar Mengajar. Jakarta: Bumi Aksara

Elyani. 2011. Penerapan Model Pembelajaran Inkuiri Terbimbing 
dalam pembelajaran Fisika untuk Meningkatkan Aktivitas Belajar Siswa pada Pokok Bahasan Getaran dan Gelombang.

Jakarta :Universitas Islam Negeri Syafrif Hidayat.

Huda, M. 2014. Model-model Pengajaran dan Pembelajaran. Yogyakarta: Pustaka Pelajar

Purwanto. 2014. Evaluasi hasil belajar. Yogyakarta: Pustaka Pelajar

Shoimin, A. 2014. 68 Model Pembelajaran INOVATIF dalam Kurikulum 2013. Yogyakarta: AR-RUZZ MEDIA

Slameto. 2013. Belajar dan Faktor-Faktor Yang Mempengaruhinya. Jakarta: Rineka Jaya

Ibrahim,Muslim.2010. Model Pembelajaran Inkuiri.

Sudjana, N. 2014. Penilaian Hasil Proses Belajar dan Mengajar. Bandung: Sinar Baru Algesindo

Suprijono, A. 2011. Cooperatif Learning. Yogyakarta: Pustaka Pelajar 